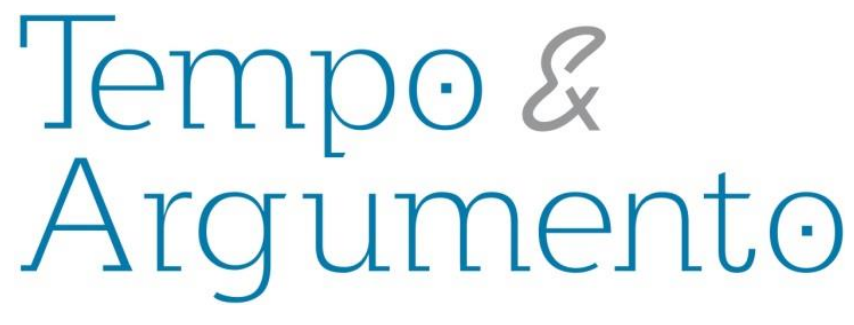

\title{
100 anos da revolução russa: ensinamentos da atuação dos anarquistas
}

\section{Resumo}

O presente artigo procura apresentar, nos 100 anos de comemoração da Revolução Russa, uma análise histórica da participação anarquista nos processos pré-revolução e durante os anos de Comunismo de Guerra. Em um segundo momento, a pesquisa busca descrever o principal movimento anarquista durante a Revolução Russa, ou seja, a atuação de Nestor Ivánovitch Makhno e seu Exército Negro na Ucrânia.

Palavras-chave: Anarquismo. Revolução Russa 1917. Movimento Makhnovista. Movimentos Sociais.

\author{
Isaías Albertin de Moraes \\ Doutorando em Ciências Sociais pela \\ Universidade Estadual Paulista Júlio de \\ Mesquita Filho (Unesp/Araraquara). Bolsista da \\ Coordenação de Aperfeiçoamento de Pessoal \\ de Nível Superior (CAPES) \\ São Paulo - BRASIL \\ isaiasalm@gmail.com
}

\section{Fernando Antonio da Costa Vieira}

Doutorado em Sociologia e Antropologia pela Universidade Federal do Rio de Janeiro (UFRJ). Estágio Pós-Doutoral na Universidade Federal Fluminense (UFF). Professor adjunto na Universidade Candido Mendes (UCAM). Rio de Janeiro - BRASIL fermavieira@uol.com.br

\section{Para citar este artigo:}

MORAES, Isaías Albertin de; VIEIRA, Fernando Antonio da Costa. 100 anos da revolução russa: ensinamentos da atuação dos anarquistas. Tempo e Argumento, Florianópolis, v. 9, n. 22, p. 339 363, set./dez. 2017. 


\title{
10oth anniversary of russian revolution: lessons of anarchists's action
}

\begin{abstract}
This article seeks to present, in the 100 years celebration of the Russian Revolution, a historical analysis of anarchist participation in the prerevolution process and during the years of War Communism. In a second moment, the research sought to describe the main anarchist movement during the Russian Revolution, the activity of Nestor Ivanovitch Makhno and his Black Army in the Ukraine.
\end{abstract}

Keywords: Anarchism. Russian Revolution 1917. Makhnovist Movement. Social Movements.

\section{Introdução}

A Revolução Russa de 1917, que comemora 100 anos em 2017, já foi demasiadamente abordada por historiadores, cientistas políticos, economistas, sociólogos, enfim, uma gama de acadêmicos de diferentes áreas se devotou a estudá-la e avaliar seus impactos e seus legados para a humanidade. Uma coisa é fato: não se consegue compreender o século XX e tampouco o mundo contemporâneo sem se dedicar ao estudo e à pesquisa sobre a Revolução Russa. Ela oferece muitas chaves para desentranhar o trágico suceder das classes e setores oprimidos e explorados do mundo moderno. 
Com isso em mente, ao propor a presente pesquisa, indagou-se como o artigo poderia contribuir para o estudo da Revolução Russa. A historiografia ofereceu diversos testemunhos, sobretudo por parte dos próprios bolcheviques que se ocuparam de contar uma história oficial, além de grandes nomes das ciências humanas que já se dedicaram ao tema como: Domenico Losurdo (2004), Edward Hallett Carr (1981), Marc Ferro (1984), Maurício Tragtenberg (1991; 2007), Daniel Aarão Reis Filho (1983, 2007a, 2007b), Rosa Luxemburgo (1991), John Reed (1978), Eric J. Hobsbawm (1984, 1986, 1995, 2010), Perry Anderson (1991), entre outros.

A resposta que se encontrou à indagação foi a de apresentar um resgate histórico crítico da participação anarquista no processo revolucionário russo de 1917, na primeira parte do texto; na segunda parte, focar, em especial, na atuação de Nestor Ivánovitch Makhno e seu Exército Negro na Ucrânia. Segundo Tragtenberg:

[...] História da Revolução Russa, muito erudita e interessante, omite dois episódios centrais: a revolução camponesa na Ucrânia, que coletivizou as terras diretamente, com Makno; e as reivindicações dos marinheiros de Kronstadt contra a ditadura de partido único e por sovietes independentes do Estado e do partido. Tais fatos não aparecem nas histórias comuns da Revolução Russa; e são muito decisivas. (TRAGTENBERG, 1991, p. 46)

Para atingir seu escopo, a pesquisa, em um primeiro momento, buscou consubstanciar o levantamento, a seleção, o fichamento e o arquivamento de informações relacionadas ao objeto estudado. Posteriormente, adotou-se uma abordagem sistemática por meio da avaliação crítica dos dados bibliográficos e históricos, de fontes primárias e secundárias. O estudo intentou, nesta fase, trazer autores atuais que estão a se dedicar ao tema e realizar a triangulação de dados, objetivando, assim, uma análise histórica mais conscienciosa dos acontecimentos vivenciados.

Verifica-se que a delimitação temática proposta pela pesquisa buscou lançar luzes em questões ainda obscuras da Revolução Russa. Alguns fatos que o artigo se empenhou em abordar, como a Revolta de Kronstadt, as diferenças entre bolcheviques e anarquistas, bem como os projetos desses para a Rússia, e o surgimento e a aniquilação do movimento makhnovista, foram, não raramente, esquecidos ou rodeados pelos historiadores. 


\section{Os Anarquistas na Revolução Russa}

No final do século XIX, o Império Russo era o país mais extenso da Europa e abrigava diferentes povos e culturas, com expressivos desequilíbrios sociais, econômicos e políticos. A Rússia Czarista era uma nação com baixo desenvolvimento industrial e com grande concentração de terras. Os czares russos governavam o império com mão de ferro por meio de uma monarquia autocrática e despótica. A monarquia era sustentada principalmente pela nobreza rural, dona da maioria das terras cultiváveis, de onde saíam os oficiais do exército e os principais dirigentes da Igreja Ortodoxa Russa. Os opositores do regime eram perseguidos por um eficiente e truculento aparelho de repressão militar, a Okhrana - polícia política do governo (WADE, 2005; TRAGTENBERG, 2007).

No período do Czar Nicolau II (1894 - 1918), houve um pequeno desenvolvimento industrial promovido, em grande medida, com capitais ingleses, alemães, belgas e franceses. Além dos capitais estrangeiros, a Rússia recebeu do exterior, em virtude desse maior relacionamento com a Europa Ocidental, novas correntes políticas que se chocavam com o antiquado absolutismo do governo russo. Entre essas, se destacaram os pensadores socialistas, como: Louis Blanc, Robert Owen, Charles Fourier, Saint-Simon, Karl Marx, Friedrich Engels e Pierre Joseph Proudhon (AVRICH, 2005).

Desses autores, os que tiveram mais influência no pensamento e no movimento anarquista russo foram: Proudhon, com sua ideia de autogestão e mutualismo, Karl Marx e Friedrich Engels, sobretudo com o materialismo dialético e a luta de classes, e os conceitos de superestrutura e infraestrutura. Os principais pensadores anarquistas russos, Mikhail Aleksandrovitch Bakunin, Piotr Alexeyevich Kropotkin e Lev Nikolayevich Tolstói tiveram influências significativas desses e de outros autores e militantes sociais.

Os anarquistas, no final do século XIX, organizavam-se em grupos autônomos, alguns com ações diretas como o Naródnaia Vólia (Vontade Popular) que agrupava, além de anarquistas, niilistas ${ }^{1}$ e narodniks ${ }^{2}$. O grupo, influenciado pelas ações de Sergey

\footnotetext{
${ }^{1}$ Durante o reinando de Alexandre II (1855-1881), surge na Rússia uma movimento niilista caracterizado pela reação contra as antigas concepções religiosas, metafísicas e idealistas herdadas (VOLPI, 1999).

${ }^{2}$ Os narodniks eram membros da elite letrada urbana russa que aderiram ao socialismo agrário, inspirados nas obras de Jean-Jacques Rousseau e Alexandre Herzen, e pregavam um regresso à vida no campo (VON LAUE, 1954).
} 
Gennadiyevich Nechayev, anarquista e niilista revolucionário e reconhecido por fomentar a revolução utilizando a violência política, conseguiu o feito de assassinar, em $1^{\circ}$ de março de 1881, o Czar Alexandre II, que estava no poder desde 1855. Encorajado por essa ação, o grupo começou a articular o assassinato de Alexandre III (governou o Império entre 18811894), no entanto a Okhrana descobriu o plano e cinco dos conspiradores, incluindo Alexandre Ulyanov, irmão mais velho de Vladimir Ilyich Ulyanov (conhecido como Lênin), foram presos e enforcados em 20 de maio de 1887 . Tal fato fez com que a repressão czarista aumentasse significativamente e importantes reformas sociais e econômicas fossem paralisadas (READ, 2005; DER KISTE, 2003).

Nesse período, foram publicados vários jornais anarquistas, como o Rabotnik (O Trabalhador), Obshchina (Comunidade), Narodnoe Delo (A Causa do Povo), apoiados por Bakunin. Entre as comunidades russas expatriadas havia o Hleb i Volya (Genebra, 1903-5), apoiado por Kropótkin, Burevestnik (Paris, 1906-10) e Rabotchi Mir (Paris, 1911-14) (WOODCOCK, 2002). Além disso, surgiram diversos grupos anarquistas que se dividiam em duas frentes: os insurrecionalistas, como Chernoe Znamia (Bandeira Negra) e Beznachalie (Sem autoridade) e os sindicalistas, como no caso do Grupo de AnarcoSindicalistas do Sul da Rússia. Esses participaram da fundação dos primeiros sovietes em Petrogrado (atualmente São Petersburgo), então capital do Império e, em Moscou, fundando a Cruz Negra Anarquista - CNA. A fundação da CNA, em 1905, ocorreu em virtude da recusa de grupos de ajuda humanitária, como a Cruz Vermelha, de prestar auxílio a presos políticos anarquistas, considerados terroristas. Entre os esforços da CNA estavam o fornecimento de literatura política e apoio legal para prisioneiros (CHRISTIE, 2004; AVRICH, 2005).

Os periódicos, as obras dos três principais autores anarquistas de língua russa (Bakunin com seu socialismo libertário, Kropótkin com o anarco-comunismo e Tolstói com um anarquismo de viés cristão), as ações de grupos anarquistas, bem como as greves, os tumultos no campo, os atentados, as demonstrações de insatisfação estudantis e o descontentamento nos militares foram algumas das condições para a Revolução de 1905 e para a formação dos sovietes, conselhos de operários e de soldados. A estrutura sindicalista revolucionária se formava com o esforço empreendido pelos anarquistas, 
socialdemocratas e socialistas na direção da revolução social. O símbolo da Revolta de 1905 foi o motim da poderosa unidade da frota do mar Negro, o encouraçado Potemkin, que se juntou aos rebeldes. As autoridades do Czar Nicolau II reprimiram violentamente as manifestações populares, e o movimento de 1905 foi abafado, tendo vários de seus líderes presos, mortos ou deportados (WADE, 2005).

O início da Grande Guerra Mundial (1914-1918) e a participação da Rússia, ao lado da França e do Reino Unido, formando a Tríplice Entente, evidenciou a fragilidade da corte e da aristocracia czarista em lidar com as questões políticas-econômicas-militares do mundo moderno-industrial. Durante a guerra, a economia russa foi à ruína. A maioria da população estava passando por necessidades enquanto especuladores obtinham intensos lucros. Nas frentes de batalhas, os soldados russos, mal armados, mal alimentandos e mal preparados, morriam aos milhares. Os operários e os camponeses se organizaram, greves eclodiram e militares começaram a desertar (WADE, 2005; CARR, 1981).

Nesse clima, surgiram vários grupos de oposição, entre eles o Partido Operário Social-Revolucionário da Rússia - POSDR. Criado em 1898, em Minsk, tinha o objetivo de reunir diversas organizações revolucionárias em um partido único, com significativa influência das teorias de Karl Marx e Friedrich Engels. O partido tinha como membros Gueorgui Plekhanov, Yuly Martov, Lênin e Lev Bronstein (conhecido como Trotsky), e focava, a despeito da matriz agrária russa, no potencial revolucionário do proletariado urbano (CARR, 1981).

A falta de organização partidária anarquista fez com que, durante a Grande Guerra Mundial, houvesse uma significativa queda nas suas atividades contra o Império Russo e em ações panfletárias entre a população e os expatriados. O movimento anarquista russo somente conseguiu se reorganizar às vésperas da Revolução de 1917. Havia, por exemplo, algumas unidades militares simpáticas à causa anarquista e uma federação que publicava um jornal diário, o Anarchy, em Moscou. Além disso, em Kronstadt, muitos marinheiros e comitês de fábricas demonstravam apoio aos ideais libertários e se opunham significativamente aos desejos de centralização dos sindicatos controlados pelos mencheviques. Entre as diversas tendências anarquistas, os anarco-sindicalitas e os 
anarco-comunistas nutriam maior simpatia dos trabalhadores e ganhavam espaço, também, em cidades como Odessa e lekaterin (ROCKER, 2007; WOODCOCK, 2002; TRAGTENBERG, 2007).

Nas primeiras semanas de março de 1917, eclodiu um movimento revolucionário na capital, Petrogrado. As tropas do exército aderiram à revolução, e até os setores mais moderados da sociedade russa abandonaram o Czar Nicolau II que acabou por abdicar do trono. Os revolucionários formaram um governo republicano provisório que continha um amplo espectro de tendências políticas, dirigido por Alexander Fyódorovich Kérensky, parlamentar eleito em 1912 para a Duma e membro do Partido Trudovique (Partido Trabalhista) de orientação pequeno-burguesa, e ligado ideologicamente aos mencheviques. Vários setores da burguesia liberal e alguns da aristocracia apoiaram o novo governo, que iniciou uma série de reformas. Entre elas se destacam: a adoção do sufrágio universal, a convocação de uma Assembleia Constituinte para depois da eventual vitória na Grande Guerra e a libertação de presos políticos (WADE, 2005; TRAGTENBERG, 2007).

Embora os sovietes continuassem a funcionar, o governo provisório tornou-se paulatinamente mais impopular em virtude de se manter na Grande Guerra Mundial e por não conseguir resolver os problemas econômicos, sociais e políticos da Rússia. Os anarquistas foram os primeiros a atacar o governo de Kérensky e convocar mais poderes para os sovietes. Dentro dos quadros partidários, no entanto, quem ganhava cada vez mais expressão ao pregar a paz com a Alemanha, a saída da Rússia da guerra, a distribuição de terras aos camponeses e o fortalecimento dos sovietes, foi Lênin, líder dos bolcheviques. Os bolcheviques tornaram-se mais numerosos, chegando a 80 mil militantes (AVRICH, 2005; ROCKER, 2007).

Quando rompeu a Revolução de outubro de 1917, os anarquistas russos participaram dos conflitos, adotando medidas de autogestão, de cooperativismo, de coletivismo, de ações diretas e de panfletagem, ganhando simpatia de diversos trabalhadores e camponeses. Foram criadas Uniões Anarco-Sindicalistas em toda a Rússia, jornais, como Golos Truda (Voz do Operário) começaram a circular em Moscou e outros periódicos foram veiculados nos distritos rurais e centrais do país (WOODCOCK, 
2002). Em lekaterinburgo, por exemplo, operários anarquistas estavam insurgindo contra o governo provisório. Segundo Rocker (2007), foi o anarquista Anatol Grigorievitch Zelesniakov que liderou os marinheiros de Kronstadt e invadiu o parlamento em Petrogrado. Esse feito e outros dos trabalhadores de Kronstadt fizeram com que, posteriormente, Trotsky os intitulasse de o orgulho e a glória da revolução russa (BERKMAN, GOLDMAN, 2011).

Em 1918, as conferências sindicalistas impulsionadas pelos anarquistas, conseguiram criar a Confederação dos Anarco-Sindicalistas Pan-Russos, a qual chegou a 88 mil membros. (SKIRDA, 2000). Foi nesse ano que os anarquistas do sul reuniram-se na Nabat (tocsin em russo/ucraniano que significa "batida de tambor"). Essa era a Confederação Alarme de Organizações Anarquistas, que abarcou todas as grandes cidades do sul da Ucrânia. (AVRICH, 2005). As atividades da Nabat, que, inclusive, publicava um jornal com o mesmo nome, estavam centralizadas, sobretudo, nas cidades de Kharkov e Kúrsk e atraíram diversos anarquistas russos mais atuantes durante o período da Revolução e de Guerra Civil, incluindo Volin, Yarchuk, Peter Arshinov, Olga Taratuta, Senya Fleshin e Aaron e Fanya Baron. Seus membros tentavam unir as várias tendências - kropotkista, cristã, individualista e sindicalista - num único movimento forte denominado de sintetismo anarquista ${ }^{3}$, e, alguns, como Volin e Tchubenko, fixaram estreitas relações com Makhno. (WOODCOCK, 2002).

Houve, na Sibéria, outro movimento liderado por anarquistas, que ficou conhecido, posteriormente, como Makhnovista Siberiana, onde aproximadamente 140 mil combatentes revolucionários agiram sob liderança de organizações simpáticas ao anarquismo. Muitos desses anarquistas siberianos tinham se exilado na região pelas suas atividades contra o Regime Czarista. Entre os grupos que se formaram na Sibéria, destaca-se o Grupo Anarquista de Tomsk que focava em propaganda, organização de forças armadas, cooperativas, sindicatos, fundos de solidariedade e expropriação de bancos e de terras. Em 1914, ocorreu uma conferência anarquista-comunista, na província

\footnotetext{
3 Corrente surgida dentro do anarquismo que buscava uma síntese entre diversas correntes anarquistas. Encontrou em Vsévolod Mijáilovich Eichenbaum, conhecido como Volin (1882-1945), seu principal teórico. Volin atuou em favor da revolução divulgando as ideias anarquistas no jornal Golos Truda (AVRICH, 2005).
} 
de Irkustk e, segundo Shtyrbul (1996), em 1917, havia 46 grupos e agrupamentos anarquistas na região com aproximadamente 800 militantes.

Percebe-se que as atividades anarquistas encontraram terreno fértil na Rússia no final do século XIX e no início do Século XX. É importante observar, entretanto, que os ideários anarquistas se desenvolveram, principalmente, nos extremos do Império Russo, ou seja, em regiões onde o Estado ou as organizações partidárias tradicionais tinham pouco acesso ou nenhum, permitindo ou criando a necessidade, assim, de maior cooperação e ajuda mútua entre os moradores dessas regiões, a Ucrânia e a Sibéria.

A segunda parte do artigo dedicar-se-á especificamente para a atuação dos anarquistas na região da Ucrânia. Todavia, antes de entrar nessa análise é importante destacar, sobre a Sibéria, as palavras de Kropotkin, que serviu no exército cossaco siberiano de 1862-1867 e escreveu: "Os conquistadores russos da Sibéria tiveram em geral tão boa impressão das práticas comunistas dos buriates que lhes deram o nome de Bratskiye -"os fraternos" - e escreveram a Moscou: Entre eles, tudo é feito em comum; tudo o que têm é compartilhado" (KROPOTKIN, 2009, p. 114).

\section{O papel revolucionário do Exército Negro}

Nestor Ivánovitch Makhno era filho de uma família humilde de camponeses de Gulyai-Polye, no sul da Ucrânia, situada na província de Ekaterinoslav. Ele nasceu em 27 de outubro de 1889, trabalhando na agricultura desde a infância. Durante a Revolução de 1905, com 15 anos, Makhno se aproximou dos anarquistas locais. Nos anos posteriores, Makhno recorre cada vez mais ao uso da violência como tática de ação, articulando incêndios de propriedades e ataques às instituições representativas do regime czarista, como distritos policiais.

Em 1908, Makhno é capturado e condenado à morte por sua militância em grupos anarquistas desde 1905 e por ações de resistências, como incêndios das propriedades senhoriais e de fazendas de Koulaks (AVRICH, 2005). No entanto, tem sua pena convertida para prisão perpétua, sendo levado para o presídio de Butyrki, em Moscou. Durante os nove anos em que ficou preso, Makhno teve contato intenso com a literatura 
anarquista e conviveu com outros companheiros anarquistas, como Piotr Arshinov (CASTRO, 2014).

Muito desse modus operandi adotado por Makhno pode ser explicado pela origem e pela história da região em que ele nasceu. Aquele território era formado por grupos étnicos de origem cossaca, com forte tradição militar, ajuda mútua, cooperativismo e de independência em relação ao poder central. A região ucraniana, na qual se desencadeou o movimento makhnovista, tinha uma população bastante expressiva, estimada em 30 milhões, e uma posição destacada na economia russa, pois era fonte de matéria-prima como carvão, minérios de ferro e manganês, além de fornecer grande quantidade de cereais (CASTRO, 2014).

Nos últimos anos do século XIX, a região assistiu a um surto modernizador, em especial na região de Donetz, onde a exploração de carvão favoreceu a industrialização, ainda que a atividade agrícola fosse o principal polo de riqueza da região. Os czares russos, desde o século XVII, ocuparam a maior parte do território da Ucrânia integrando-o ao Império Russo e iniciando um processo de russificação da região. Esse resultou numa tomada de consciência de uma identidade ucraniana, buscando a defesa da própria língua ucraniana e a preservação de sua história.

O ano de 1917 marcou o Império Russo com o vitorioso movimento de fevereiro que derrubou o czarismo e instalou um governo provisório com a liderança de Kérensky. Com a Revolução de Fevereiro de 1917, Makhno é libertado. Após sua soltura, Makhno volta para sua região, na dispersa vila ucraniana de Gulyai-Polye, com uma população de aproximadamente 30 mil habitantes, sua maioria de agricultores, no extremo sul do Império Russo e se torna presidente do soviete local, reorganizando o movimento anarquista (AVRICH, 2005; ROCKER, 2007).

A Revolução de Fevereiro repercutiu de forma diferenciada na Ucrânia. A fragilidade inicial dos bolcheviques e o papel dos anarquistas e dos nacionalistas ucranianos resultaram numa certa indiferença ante o governo de Kerensky. Isso gerou fragmentação na política ucraniana, impedindo uma posição mais coesa no contexto revolucionário. O decreto do Governo Provisório que concedia terras aos camponeses, 
desde que pagassem por elas, não conseguiu consolidar apoio junto aos camponeses ucranianos, mas, por outro lado, distanciou-os dos grandes proprietários rurais. Além disso, outra ameaça surgia na região: Lavr Gueórguievich Kornilov, general do Exército Imperial Russo, preparava sua marcha contrarrevolucionária em agosto (FEDELI, 1972).

Diante desse cenário, o Comitê Central Executivo dos Sovietes recomendou a organização para a defesa do avanço kornilovista, logo Makhno tomou a frente em sua região, constituindo o Comitê de Defesa da Revolução. Makhno conseguiu unir os sovietes locais com o grupo anarquista-comunista, com uniões operárias das usinas e das fábricas e com soldados, surgindo a união de camponeses e operários, além do Exército Makhnovista - que, em seu auge, chegou a contar com aproximadamente 110 mil homens e era conhecido também por Exército Negro, em virtude de sua bandeira preta anarquista (AVRICH, 1968, 2005).

Nas áreas de influência do movimento makhnovista, eram organizadas expropriação de propriedades agrícolas, tomada de fábricas, combate ao governo de Kerensky e dos mencheviques e programas de autogestão e mutualismo, visando a formação de "sovietes livres". Segundo Makhno, "nem esse governo e nenhum outro seriam tolerados. Cessaríamos de pagar os arrendamentos aos proprietários de terras. Ocuparíamos as terras dos 'fidalgos' e das comunidades religiosas assim como as fábricas e usinas" (MAKHNO, 1988, p.70). Em agosto de 1917, ou seja, seis meses depois de sua soltura e dois meses antes de eclodir a Revolução de Outubro, Nestor Makhno já tinha conseguido realizar, em sua região, a divisão das propriedades locais entre os sem-terra e entregar as indústrias do distrito nas mãos dos operários (WOODCOCK, 2002; TRAGTENBERG, 2007).

O anarco-comunismo e outras correntes anarquistas, como por exemplo, o sintetismo anarquista, vão se aproximar dos camponeses ucranianos, mormente, em Ekaterinoslav - enquanto os bolcheviques ampliam sua liderança junto ao operariado, principalmente em Kiev. Ambos os movimentos possuíam uma vigorosa defesa da reforma agrária, do fim da propriedade privada no campo e da tomada das fábricas pelos trabalhadores; no entanto, os anarquistas questionavam o centralismo, o estadismo e o autoritarismo bolchevique. 
Em resposta ao avanço makhnovista e bolchevique, os nacionalistas burgueses ucranianos se organizaram em torno do movimento político no Congresso Nacional de toda a Ucrânia, realizado em abril de 1917, que estruturou a chamada Rada Central em Kiev. Embora reconhecesse a autoridade do Governo Provisório, a Rada assumiu o vácuo czarista e buscou ampliar a autonomia da Ucrânia e barrar a agitação revolucionária, ao mesmo tempo em que procurou conter e esvaziar os sovietes. $O$ engrandecimento da Revolução de Outubro acirrou as tensões com a Rada Central, assumindo franca oposição ao governo bolchevique e preponderância na luta contrarrevolucionária e com apoio de forças militares estrangeiras. Nesse ensejo, a União Operária Camponesa de Makhno reagiu e ampliou sua influência e seu contingente militar ao confiscar cada vez mais armas da burguesia e ganhar apoio de soldados (VOLIN, 1977).

Os bolcheviques, que de maneira geral sempre foram pouco presentes na Ucrânia, conclamaram o apoio do Exército Negro, liderado por Makhno, a se juntar na luta pela derrocada dos inimigos da revolução. Em janeiro de 1918, a Rada Central iniciou nova ofensiva contra o poder revolucionário junto com o Exército Branco. A ofensiva era comandada pelo general Alexei Maximovich Kaledin. Tropas cossacas abandonavam a frente militar e retornavam à Ucrânia para se juntar às tropas de Kaledin que contou também com a simpatia das tropas alemãs acantonadas na região (VOLIN, 1977; AVRICH, 1968, 2005).

Após intensa batalha, o Exército Negro e alguns bolcheviques conseguiram a vitória em 25 de janeiro de 1918 e tomaram Kiev. No entanto, as contradições dos bolcheviques na lida com os demais grupos revolucionários, como os anarquistas, resultaram num afastamento da aliança inicial, dentro de um contexto de reforço da centralização e do autoritarismo do poder bolchevique (TRAGTENBERG, 2007).

Sobre os anarquistas neste momento, Makhno disse:

O anarquismo não aspira ao poder político [Estado] nem à ditadura. Sua principal aspiração é ajudar as massas a tomar o caminho autêntico da revolução social e da construção do socialismo. Mas não é o bastante que as massas tomem o caminho da revolução social. É também necessário manter esta orientação de revolução e seus propósitos: a superação da 
sociedade capitalista em nome dos trabalhadores livres. Como a experiência da Revolução Russa de 1917 nos mostrou, esta última tarefa está longe de ser fácil, principalmente por causa dos inúmeros partidos que tentam orientar o movimento para uma direção oposta à da revolução social. [...] As massas exigem uma resposta clara e precisa dos anarquistas a respeito destas e de muitas outras questões. E, a partir do momento em que os anarquistas declaram uma concepção de revolução e da estrutura da sociedade, eles são obrigados a dar uma resposta clara à todas estas questões, relacionar a solução destes problemas à concepção geral de comunismo libertário, e devotar todas suas forças à realização destes. (MAKHNO, 2001, p. 46)

A tensão entre bolcheviques e o Exército Negro se acirrou ainda mais, com a assinatura, em 3 de março de 1918, do Tratado de Brest-Litovski entre a Rússia bolchevique, o Império Alemão, a Bulgária, o Império Austro-Húngaro e o Império TurcoOtomano. O tratado, questionado por Leon Trotsky e Nikolai Ivanovich Bukharin, mas defendido por Lênin, apontava a necessidade de garantir o apoio popular aos bolcheviques, retirando a Rússia da Grande Guerra e assinando um armistício. Esse resultou na incorporação - de forma concreta - da Polônia, dos Países Bálticos e da Finlândia para o Império Alemão - e que após o fim do conflito vão conquistar a sua independência - e, da Ucrânia para o controle Austro-Húngaro (VOLIN, 1977).

Em junho de 1918, Makhno fora a Moscou para um encontro entre as principais lideranças revolucionárias russas. Nesse momento, Makhno é apresentado a Lênin pelo presidente do Comitê Executivo Pan-Russo dos Sovietes, lákov Mikháilovitch Sverdlov que nutria admiração pelo líder ucraniano. Os três têm uma conversa no Kremlin que o próprio Makhno transcreve parte do diálogo.

Lênin, dirigindo-se ao camarada Sverdlov, disse:

- Os anarquistas sempre estão dispostos a toda classe de sacrifícios; são abnegados, mas também cegos e fanáticos. Deixam escapar o presente por um futuro distante.

Voltando-se para mim, pediu que não me desse por citado nestas palavras.

- A você, camarada, - afirmou - considero como um homem realista, que está preocupado com os problemas atuais. Se na Rússia tivéssemos pelo menos uma terça parte desta classe de anarquistas, nós, os comunistas, 
estaríamos dispostos a colaborar com eles, sob certas condições, em prol da livre organização da produção.

Adverti que começava a estimar a Lênin, a quem até fazia pouco tempo havia considerado como o culpado pela destruição de todas as organizações anarquistas de Moscou, o que foi o sinal para destruir as de outras muitas capitais da Rússia. Em meu interior começava a envergonhar-me de mim mesmo e buscava rapidamente uma resposta adequada. Disse o seguinte:

- Todos os anarquistas apreciam muito a Revolução e suas conquistas. Isto demonstra que, neste sentido, todos somos iguais.

- Não me diga isto - retrucou, rindo, Lênin - Nós conhecemos os anarquistas tanto como você mesmo os conhece. A maioria deles, ou não pensam nada sobre o presente, ou pensam bem pouco, apesar da gravidade da situação. E para um revolucionário é vergonhoso não tomar resoluções positivas sobre o presente. A maioria dos anarquistas pensam e escrevem sobre o porvir, sem entender o presente. Isto é o que nos separa a nós, os comunistas, dos anarquistas. (Diálogo entre Makhno e Lênin. Extraído de The Nestor Makhno Archive)

Nessa reunião, os bolcheviques buscavam ampliar suas alianças junto aos setores de esquerda, tanto os socialistas revolucionários, os socialdemocratas quanto os anarquistas. Para Lênin, Trotsky e outros líderes bolcheviques, o movimento anarquista apresentava certa ambiguidade e risco ao recém e imaturo processo revolucionário.

Após voltar de Moscou, Makhno encontra o Exército Negro sem apoio do Exército Vermelho e tem de enfrentar uma luta de resistência frente à ocupação estrangeira austro-alemã e contra as tropas contrarrevolucionárias da Rada. O grupo de Makhno inicia atividades de guerrilha e ações de franco-atiradores, além de organizar emboscadas e regimentar os camponeses e os operários para se voluntariarem, fortalecendo, assim, seu Exército Insurrecional Revolucionário. Em dezembro de 1918, o exército austroalemão e seu testa de ferro, Ivan Skoropadsky, são derrotados por Makhno e seus homens, sem o apoio dos bolcheviques que cumpriam o Tratado de Brest-Litovski (VOLIN, 1977).

Pode-se afirmar que a resistência dos trabalhadores ucranianos, sobretudo os camponeses da região de Ekaterinoslav, foi essencial para a defesa de toda a Revolução Russa. A experiência histórica da Comuna de Paris (1871) demonstrava que uma contrarrevolução mediante uma invasão externa, resultante da união interestatal de 
interesses burgueses e de nobres conseguia inviabilizar levantes como os que vinham acontecendo na Rússia.

Em virtude dessa maior complexidade de batalha enfrentada pelo Exército Negro, os nacionalistas voltam a ganhar espaço em certas regiões sob o comando do general Symon Petlyura e retomam a ofensiva em direção ao Dniper e à Kiev. Além disso, o Exército Branco, agora liderado pelo General Anton Ivanovich Denikin, também avança sobre a região. Diante da saída do austro-alemães e com o ressurgimento dos nacionalistas e dos brancos, os bolcheviques resolvem reinvestir no conflito. É nesse momento que o Exército Revolucionário Insurrecional Makhnovista opta por defender os sovietes a todo custo e a lutar novamente ao lado do Exército Vermelho, porém mantendo sua organização interna, seu nome e suas simbologias (bandeiras e roupas pretas), algo que desagradava Trotsky (VOLIN, 1977; ROCKER, 2007).

A força do grupo anarquista e a derrota dos contrarrevolucionários, na maior parte da Ucrânia, provocaram uma virada nas posições defendidas pelas lideranças bolcheviques. Para esses, seria preciso fortalecer as lideranças bolcheviques ucranianas em detrimento do grupo makhnovista. Em várias ocasiões, desse modo, durante as batalhas contra o Exército Branco, os bolcheviques não cumpriram o combinado com o Exército Negro, como o fornecimento de munições, armas e apoio tático, fazendo com que esse enfrentasse, em condições difíceis, o Exército Branco e tendo diversas baixas. (JOLL, 1964); (ROCKER, 2007).

Sobre essa situação Galina Makhno, companheira de Nestor relata:

Ele compreendeu a sinistra conspiração contra ele, mas se recusou a voltar suas armas contra os bolcheviques. A causa da Revolução lhe era muito cara. Decidiu então deixar seu comando no Exército Vermelho e advertiu Moscou. Lançou um apelo aos insurretos para que continuassem a combater os brancos [...] (MAKHNO, 2001, p. 69)

No entanto, no fundo, Makhno sabia das limitações anarquistas para estabelecerem autogestão, principalmente nas cidades. Em suas memórias da revolução, ele afirma sobre os anarquistas: 
[...] não puderam ter sobre o país uma influência revolucionária comparável à desses dois partidos [bolcheviques e SR-esquerda] que tinham formado um bloco político sob a direção deste mesmo astucioso Lênin e sabiam exatamente aquilo que deviam empreender antes de mais nada neste momento e de que força e energia podiam dispor. (MAKHNO, 1988, p. 156)

Verifica-se que, no fim de 1918, durante a Guerra Civil, quatro forças militarespolíticas expressivas e diferentes estavam em ação na Ucrânia: 1) Petliurovstchina, movimento nacionalista, de nome oficial Rada, composto pela burguesia nacional, e que conseguiu uma adesão de segmentos das frações trabalhadoras; 2) Bolchevismo, 0 Partido/Estado; 3) Exército Branco, reacionários com apoio da Entente e 4) Makhnovista, Exército Revolucionário Insurgente de base camponesa e orientação anarquista.

A Rada Central tinha seu maior poder em Kiev onde disputava constantemente com os bolcheviques que tinham mais abrangência entre os operários urbanos do que os maknovistas. Os acúmulos de vitórias das tropas makhnovistas vão ampliar sua influência em grande parte do sul da Ucrânia, na província de Ekaterinoslav. Nesse sentido, Makhno e seu grupo iniciaram a transformação das áreas libertadas em direção ao projeto socialista libertário. Eles estabeleceram comunas livres denominadas Comuna Rosa Luxemburgo, Comuna 1, 2 e 3, além de diversos Comitês Comunais e passaram o comando das fábricas para os trabalhadores.

Nesse processo o movimento machnovista desarma a burguesia, combate os destacamentos cossacos que lutam ao lado do exército branco e confiscam todas as usinas. Nesta região da Ucrânia entre 1918 e 1920 sobre coordenação da União dos Camponeses de Goulai-Polé, do Soviete de Deputados Camponeses e operários e do grupo anarquistacomunista de Goulai-Polé são colocada em práticas o auto-governo dos trabalhadores, sobre o lema: "Liberdade ou Morte" e "Terra para os Camponeses, e Fábricas para os Operários”. (CASTRO, 2014, p.07)

A incapacidade de se efetuar um acordo que garantisse os interesses dos grupos anarquistas provocou uma ofensiva política bolchevique contra os makhnovistas. As tentativas de aproximação, que se estruturam ao longo de 1919, fracassam à medida que as lideranças makhnovistas não aceitavam se colocar subalternizadas ante Moscou e aos 
bolcheviques. Considerados traidores da revolução e declarados contrarrevolucionários, os makhnovistas foram obrigados a lutar contra os grupos bolcheviques, em especial, na região de Ekaterinoslav (VOLIN, 1977; ROCKER, 2007; TRAGTENBERG, 2007).

O ano de 1920 vivenciou o horror da Guerra Civil. Na Ucrânia, os brancos eram liderados pelo general czarista Pyotr Wrangel e conseguiram retomar ímpeto militar, ameaçando a continuidade da revolução social e os anseios da liderança revolucionária bolchevique. Mais uma vez, o Exército Negro foi chamado para a luta contra o inimigo comum da revolução. Nesse contexto, as autoridades bolcheviques buscaram acertar com os makhnovistas um novo pacto político. Firmado em 16 de outubro de 1920, o pacto tinha em sua essência os seguintes eixos:

$1^{\circ}$ Libertação imediata de todos os revolucionários presos e cessação de todas as perseguições em território da república soviética contra todos os makhnovistas e anarquistas que não combaterem de armas na mão contra o governo soviético.

$2^{\circ}$ Completa liberdade de agitação, pela palavra e pela escrita, para todos makhnovistas e anarquistas, suas ideias e seus princípios, sob controle de censura militar, na medida em que se trata de questões militares. $O$ governo soviético põe a disposição do makhnovistas e anarquistas, que ele reconhece como organização revolucionária, todo material necessário para impressão e publicação de livros, revistas, jornais, e isso na base das regras técnicas gerais em vigor para as publicações desse gênero.

$3^{\circ}$ Livre participação nas eleições aos sovietes, bem como o direito para os makhnovistas e anarquistas se tornarem membros dos sovietes; é-lhes garantida, além disso, a livre participação na preparação do próximo $\mathrm{V}$ Congresso dos Sovietes na Ucrânia previsto para dezembro 1920. (ROCKER, 2007, p.63)

O acordo permitiu uma pausa numa luta em duas frentes para os makhnovistas: o das forças contrarrevolucionárias e dos bolcheviques. Entretanto, a paz foi efêmera; avançando na luta contra os brancos, expulsando as tropas estrangeiras do país, os bolcheviques, com apoio do Exército Negro, conseguiram derrotar as tropas de Wrangel na Crimeia em novembro de 1920; era a hora de resolver a disputa com os anarquistas (ROCKER, 2007). 
A nova tentativa de união entre os anarquistas makhnovistas e os bolcheviques, se de um lado ocorreu em nome da revolução social e pela sobrevivência dos ganhos anarquistas na região, pelo lado de Moscou se deu em virtude de um pragmatismo político-militar. Isso ficou claro, pois já em 1918, Lênin vinha prendendo anarquistas; e Trotsky diversas vezes se referia aos anarquistas como bandidos. O Comitê de Emergência, a Tcheka bolchevique, efetuou batidas aos escritórios do jornal Anarchy, em Moscou, e as atividades anarquistas em Petrogrado eram suprimidas (WOODCOCK, 2002).

Em 25 de dezembro de 1920, foi organizado em Kharkov, um congresso com as forças políticas dos diversos grupos anarquistas. Cerca de 400 delegados compareceram ao encontro. Numa ação rápida e precisa, na véspera do Congresso, as lideranças anarquistas foram detidas e julgadas por atividades contrarrevolucionárias. Em 1921, Fanya Baron e oito companheiros foram fuzilados nos porões das prisões da Tcheka, em Moscou. Até mesmo os seguidores do anarquismo cristão de Tolstói começaram a ser mortos em razão de se recusarem a servir ao Exército Vermelho, em virtude de seu viés fortemente pacifista. Os demais anarquistas notórios como Volin e Arshinov foram exilados (WOODCOCK, 2002).

O auge da perseguição anarquista e aos críticos do centralismo, do autoritarismo e do estadismo bolchevique se deu, todavia, em março de 1921, na cidade portuária de Kronstadt, localizada na ilha de Kotlin, no golfo da Finlândia. Durante 16 dias, anarquistas, socialdemocratas e alguns comunistas se revoltaram contra o governo bolchevique, que eles mesmos ajudaram a colocar no poder. O grupo que era composto, sobretudo, de anarquistas, estabeleceu uma comuna revolucionária, liderado por Stepan Petrichenko, marinheiro anarquista de origem ucraniana, pregando os ideários de todo poder aos sovietes (ARVON, 1984; BERKMAN, GOLDMAN, 2011; TRAGTENBERG, 2007).

Os rebelados exigiam diversas reformas, pois acreditavam que a Revolução de Outubro estava perdendo o rumo. Entre as exigências destacam: eleições para novos líderes sovietes, direito à reunião e liberdade para sindicatos e organizações camponesas, a libertação de todos os presos políticos dos partidos socialistas e marinheiros militares de organizações operárias e camponesas, liberdade econômica para camponeses e para 
operários, liberdade de imprensa, dissolução do aparato burocrático repressivo criado durante a guerra civil, ou seja, fim do monopólio bolchevique no poder (AVIRCH, 1968; BERKMAN, GOLDMAN, 2011).

Os revoltosos de Kronstadt, que antes eram nomeados a honra e a glória da Revolução, foram acusados de estarem a serviço de contrarrevolucionários estrangeiros, mesmo tendo participado ativamente das Revoluções de 1905 e de 1917. O Exército Vermelho, comandado por Mikhail Tukhachevsky, e os rebelados lutaram durante 10 dias, entre, 08 e 18 de março de 1921, sobre as águas congeladas em torno da fortaleza. Houve baixas significativas de ambos os lados, até a vitória das tropas bolcheviques em 18 de março. Houve fuzilamento e extradição por parte do Exército Vermelho e oito mil rebelados conseguiram fugir para Finlândia (ARVON, 1984; BERKMAN, GOLDMAN, 2011).

Muitos dizem que o episódio de Kronstadt tinha de ser reprimido, visto que a Rússia estava cercada. Mas o fato é que Kronstadt era a vanguarda da revolução e fornecia a guarda pessoal para o palácio de Lênin, depois de 1917. Kronstadt deseja quê? Deseja sovietes independentes do partido e do Estado, no sentido original da idéia de soviet: uma autoridade suprema que não se subordina a ninguém. (TRAGTEMBERG, 1991, p. 46)

Importante ressaltar que Trotsky, comandante maior do Exército Vermelho, na época, e que esteve em Kronstadt durante a revolta, ironicamente, mais tarde, em seu exílio no México, defenderia várias das exigências feitas pelos revoltosos contra o totalitarismo de Josef Vissarionovitch Stalin.

Em 1921, era a vez das tropas makhnovistas serem perseguidas pelo Exército Vermelho que estava consolidado em Kiev e em outras grandes cidades ucranianas. Gulyai-Polye, dessa forma, foi cercada e tomada pelos bolcheviques. Em agosto, com reduzidos soldados, o Exército Negro se dissolveu. Makhno, usando as suas ligações com acadêmicos, ativistas e escritores anarquistas e socialistas se exilou em Paris, onde se tornou escritor e defensor da causa anarquista até sua morte em 6 de julho de 1934.

Sobre esse avanço bolchevique e, praticamente, o desaparecimento dos ideários anarquistas na Rússia durante a Guerra Civil, veja que diz o anarquista Piotr Arshinov: 
Adquirimos o hábito de atribuir a derrota do movimento anarquista de 1917-19 na Rússia à repressão estatal do Partido Bolchevique, o que é um grande engano. A repressão bolchevique impediu que o movimento anarquista se expandisse durante a revolução, mas ela não foi o único obstáculo. A impotência interna do movimento em si foi uma das principais causas dessa derrota, uma impotência procedente da lentidão e da indecisão que caracterizavam diferentes afirmações políticas relacionadas a organização e tácticas.

O anarquismo não tinha opinião firme e concreta sobre os problemas essenciais da revolução social; uma opinião indispensável para satisfazer a procura das massas que criaram a revolução. Os anarquistas exaltam o princípio comunista que diz "a cada um segundo suas habilidades, a cada um segundo suas necessidades", mas nunca se preocuparam em aplicar esse princípio à realidade, embora possuíssem certos elementos duvidosos para transformar esse grande princípio em uma caricatura do anarquismo - lembre-se de quantos vigaristas se beneficiaram apoderando-se dos bens da colectividade e juntando-os aos seus lucros pessoais. (Resposta de Piotr Arshinov a Errico Malatesta publicado em Dielo Trouda, n. ${ }^{\circ}$ 30, maio de 1928, páginas 4-11. Extraído de The Nestor Makhno Archive)

A vitória bolchevique implicou no desmonte das ações dos revolucionários de Gulyai-Polye e nas incipientes construções dos "sovietes livres", baseados em sistemas auto gestionários coletivos; e marcou a centralização e o autoritarismo dos bolcheviques sediados em Moscou. Mais do que isso, os bolcheviques assinalavam a incapacidade de construir um Estado que incorporasse diversas matrizes socialistas.

\section{Considerações Finais}

A Revolução Russa de 1917 é um dos processos sócio-político-econômico mais importantes da história moderna. Após 100 anos de sua eclosão, ainda merece debates, estudos e pesquisas. A complexidade do movimento - que contava com forças revolucionárias niilistas, socialistas marxistas, socialistas utópicos, socialdemocratas, socialistas libertários, anarquistas sindicalistas, anarco-comunistas, anarquistas cristãos, nacionalistas, populistas, entre outros, além das lutas de classe e dos embates de interesses entre o campo e a cidade - faz com que a delimitação temática, para uma pesquisa mais apurada seja de profunda relevância. 
Nesse sentido, o artigo optou em apresentar um capítulo ainda pouco explorado pela literatura brasileira, mas extremamente decisivo para a compreensão das pluralidades de organizações políticas da classe trabalhadora que atuaram como sujeitos revolucionários, a presença anarquista e, sobretudo, o movimento makhnovista na Ucrânia. A escolha dessa temática procurou respeitar critérios metodológico-teóricos e histórico-documentais, como foi apresentado na introdução, porém é possível acrescentar que a pesquisa buscou, ademais, a responder certa demanda de movimentos sociais contemporâneos. Recentemente, o Brasil, seguindo uma onda, também, presente em alguns países ocidentais, vem observando o crescimento de grupos, de ações, de militantes e de simpatizantes que se autodenominam anarquistas.

Tendo isso em mente, o artigo buscou, portanto, apresentar a pluralidade de projetos que caracterizaram a Revolução Russa, realçando, em especial, a luta anarquista. Num contexto de fortalecimento do projeto bolchevique impulsionado pala liderança de Lênin, que ganhara força desde as Teses de Abril de 1917, o movimento makhnovista, que almejava construir uma alternativa ao projeto bolchevique, resgatando um ethos ucraniano e focando no anarquismo, ainda que, anelando aproximações com os bolchevistas, foi aos poucos perdendo espaço. Entre 1918 e 1921, a intelligentsia bolchevique conseguiu explorar os movimentos populares espontâneos, libertários e socialistas e tomar o poder do Estado russo, construindo, inclusive um exército estatal em detrimento de um popular. $\mathrm{E}$ depois usar esse poder do estatal para sufocar os sovietes livres e os conselhos de trabalhadores, tirando, assim, o controle dos camponeses e dos operários do protagonismo revolucionário, passando-o para o Estado.

A repressão ao forte movimento anarquistas na Ucrânia e ao levante de Kronstadt sinalizou, por parte de Lênin, Trotsky e de outros importantes nomes bolcheviques, que a única alternativa revolucionária a ser aceita seria a comandada pelo partido. Ficou evidente que os bolcheviques não foram capazes de permitir arranjos políticos que concedessem um maior grau de autonomia aos sovietes, aos conselhos e aos exércitos populares.

Acredita-se que apesar de terem se passado 100 anos da Revolução Russa e dos embates entre bolcheviques, mencheviques, nacionalistas e anarquistas, como o artigo 
tentou descrever, as diversas vertentes da esquerda socialista ainda enfrentam alguns dos mesmos importantes dilemas da época, e entram em constantes embates. Tal fato acaba inviabilizando uma coesão programática transformadora da estrutura socialeconômica-política, abrindo espaço para o fortalecimento do estamento burocrático profissional, de setores antirreformistas, de reacionários e de fundamentalistas.

Infere-se que a pesquisa, desse modo, buscou demonstrar que o resgate histórico crítico, dos grupos anarquistas presentes na Revolução Russa - berço de notáveis autores do movimento - e da experiência revolucionária makhnovista é fundamental para compreender e esclarecer, não somente o passado, mas o presente, que conta com uma pluralidade de representatividade ideológica política da classe trabalhadora cada vez maior.

\section{Referências}

ANDERSON, Perry. "Prefácio". In: DEUTSCHER, I. Marxismo, guerras e revoluções. São Paulo: Ática, 1991.

ARVON, Henri. A Revolta de Kronstadt. São Paulo: Ed. Brasiliense, 1984.

AVRICH, Paul. The russian anarchists. Oakland: AK Press, 2005.

AVRICH, Paul. Russian Anarchism and the Civil War. The Russian Review, p.296-306, jul. 1968. Disponível em: <http://sites.bu.edu/revolutionaryrussia/files/2013/og/RussianArnarchists.pdf>. Acesso em 25 de ago. 2016.

BERKMAN, Alexander; GOLDMAN, Emma. Kronstadt. Piracicaba: Ateneu Diego Giménez, 2011.

CARR, Edward. H. A Revolução Russa de Lenin a Stalin 1917-1929. Rio de Janeiro: Zahar, 1981. 
CASTRO, Rômulo de Souza. Nestor Makhno: a crítica à autoridade e ao estatismo na destruição da Revolução Russa. Rio de Janieiro: IFCS - UFRJ: 2014. Disponível em: <www.otal.ifcs.ufrj.br/wp-content/uploads/2014/04/Artigo_Makhno_V Final.doc >. Acesso em 10 de nov, 2016.

CHRISTIE, Stuart. Edward heath made me angry. EUA: ChristieBooks., 2004.

DER KISTE, John Van. The romanovs:1818-1959. Londres: Sutton Publishing, 2003.

FEDELI, Ugo. El ejército insurreccional makhnovista en la gran revolución de octubre. Barcelona: Grupos Obreros Autónomos, 1972. Disponível em: <http://www.milgac.info/spip.php?page=article_es\&id_article=204>. Acesso em 05 de nov. 2016.

FERRO, Marc. O ocidente diante da revolução soviética. São Paulo: Ed. Brasiliense, 1984.

HOBSBAWM, Eric. A história do marxismo: vol. III: o marxismo na segunda Internacional: segunda parte. Rio de Janeiro, Paz e Terra. v.3, 1984.

HOBSBAWM, Eric J. História do marxismo: vol. VII: o marxismo na época da terceira internacional: a URSS da construção do socialismo ao stalinismo. Rio de Janeiro, Paz e Terra, 1986.

HOBSBAWM, Eric. A era dos extremos. O breve século XX 1914-1991. São Paulo: Companhia das Letras, 1995.

HOBSBAWM, Eric. Podemos Escrever a História da Revolução Russa? In: Hobsbawm, Eric. Sobre história: ensaios. São Paulo: Companhia das Letras, 2010.

JOLL, James. Anarquistas e anarquismo. Lisboa: Publicações Dom Quixote, 1964.

KROPOTKIN, Piotr. Ajuda mútua: um fator de evolução. São Sebastião: Ed: A Senhora, 2009.

LOSURDO, Domenico. Fuga da história? a Revolução Russa e a revolução chinesa vistas de hoje. Rio de Janeiro: Ed. Revan, 2004.

LUXEMBURGO, Rosa. Revolução Russa. Rio de Janeiro: Vozes, 1991.

MAKHNO, Nestor. A revolução contra a revolução. São Paulo: Cortez, 1988.

MAKHNO, Nestor. Anarquia e organização. São Paulo: Luta Libertária, 2001. 
READ, Christopher. Lenin. Abingdon: Routledge, 2005.

REED, John. 10 dias que abalaram o mundo. São Paulo: Globo, 1978.

REIS FILHO, Daniel Aarão. Rússia, 1917-1921: os anos vermelhos. São Paulo: Brasiliense, 1983.

REIS FILHO, Daniel Aarão. As revoluções russas e o socialismo soviético. São Paulo: UNESP, 2007 .

REIS FILHO, Daniel Aarão. Uma revolução perdida: a história de socialismo soviético. São Paulo: Fundação Perseu Abramo, 2007b.

ROCKER, Rudolf. Os Sovietes traídos pelos bolcheviques. São Paulo: Hedra, 2007.

SKIRDA, Alexandre. Les anarchistes russes, les sovietes et la révolution de 1917. Paris: Éditions de Paris, 2000.

SHTYRBUL, Anatoli. The anarchist movement in siberia in the first quarter of the 20th century. Vol. 1 - 1900-1918 e Vol. 2 -1918-1925. Omsk: Omsk State Pedagogical University, 1996.

THE NESTOR MAKHNO ARCHIVES. O velho e o novo no anarquismo (resposta ao companheiro Malatesta.) Piotr Arshinov. May 1928. Disponível em: <http://www.nestormakhno.info/portuguese/velho-novo.htm>. Acesso em 25 de junho de 2016.

THE NESTOR MAKHNO ARCHIVES. Makhno e Lênin: um diálogo histórico. Nestor Makhno 1918. Disponível em: <http://www.nestormakhno.info/ portuguese/makhnolenin.htm>. Acesso em 23 de junho de 2016.

TRAGTENBERG, Maurício. Revolução Russa. São Paulo: UNESP, 2007.

TRAGTENBERG, Maurício. Rosa Luxemburgo e a crítica dos fenômenos burocráticos. In: LOUREIRO, I. M.; VIGEVANI, T. Rosa Luxemburgo: a recusa da alienação. São Paulo: Unesp, 1991.

VOLPI, Franco. O niilismo. São Paulo: Loyola, 1999.

VOLIN. La revolución desconocida. Buenos Aires: Proyección, 1977. 
VON LAUE, Theodore H. The Fate of Capitalism in Russia: The Narodnik Version. The American Slavic and East European Review. v. 13, n.1, p.11-28, feb., 1954. Disponível em: <https://www.cambridge.org/core/journals/american-slavic-and-east-europeanreview/article/fate-of-capitalism-in-russia-the-narodnik-

version/C5A1A37703523353CB82D487C2DFD81A> Acesso em 07 de jul. 2017.

WADE, Rex A. The Russian Revolution, 1917. Cambridge: Cambridge University Press, 2005 .

WOODCOCK, George. História das idéias e movimentos anarquistas: vol. 2. Porto Alegre: LP\&M, 2002. 